\title{
The Effect of Satisfaction of Basic Psychological Needs on Sporting Behavior in Physical Education \\ Abstract
}

\author{
Hikmet Turkay \\ Gumushane University, Turkey \\ Study Area: Gümüshane, Turkey \\ Coordinates: $40^{\circ} 27^{\prime} 35$ ? N $39^{\circ} 28^{\prime} 40$ ?E
}

Key words: Autonomy, Efficacy, Sportsmanship

\section{Introduction:}

Education is defined as a holistic system that deals with individuals in their mental, physical, psychological, and sociological aspects. The physical, psychological, sociological, and mental development of individuals is parallel to the development of healthy societies and the correct education of individuals in this context is of great importance for society.

Self-efficacy and self-confidence gains of individuals, especially through physical activity in physical education courses during school periods, also help to satisfy basic psychological needs (Ritchie et al., 2003; Warburton et al., 2006). Metaphorically, just as water, minerals, and sunlight are very important for plants to bloom, it is necessary to satisfy basic psychological needs for people to develop, realize their potential, and be protected from processes that adversely affect their health (Van den Broeck et al., 2008). Researchers predict that satisfying psychological needs in individuals increase social welfare in all areas of society (Reeve \& Jang, 2006; Vlachopoulos et al., 2011).

Three basic psychological needs that are innate and do not have a universal and hierarchical order have been proposed: autonomy, efficacy, and relationship. In particular, the need for autonomy is defined as the desire of people to experience ownership of their behavior and involves acting with a sense of will. This sense of will can be achieved by having the opportunity to make personal choices and at the same time fully accepting an externally encouraged demand. The need for efficacy is related to the effects of individuals on their ongoing interactions with the social environment and their degree of experiencing opportunities. The need for an association is defined as the degree to which the individual feels a sense of belonging and commitment to others (Deci \& Ryan, 200o; Soenens et
In order to examine the basic psychological needs of the students, 372 students studying in secondary schools were selected. In the research, it was found that there were differences between the students according to age, gender, participation in out-of-school activities, and social identification variables. As a result, it can be said that there was a relationship between the satisfaction of basic psychological needs of individuals and sporting behaviour in physical education.

al., 2007; Van den Broeck et al., 2008). The psychological health and behavior of an individual depend on the degree to which these basic psychological needs are satisfied (Deci \& Ryan, 2000). In this case, it is useful to clarify the following issue about satisfying psychological needs and their behavioral reflections: sportsmanship. Sportsmanship is a concept that includes features such as self-control, self-confidence, respecting, and not underestimating others, sincerity, courtesy, patience, kindness, and generosity (Koc, 2013). The question arising at this point: Does the satisfaction of the psychological needs of individuals affect sporting behaviors?

There is such an emphasis on winning in general and being "number one" that sometimes the concept of sportsmanship is almost forgotten. However, teachers and coaches have great responsibilities in teaching, sampling, implementing, and encouraging sportsmanship. In an environment of sporting activities, the individual learns to love winning and to strive for it, but also to hate losing and if necessary, to digest it (Clifford \& Feezell, 2010). The fact that individuals gain sporting behavior in physical education classes at school, especially in childhood, is socially promising both in the present time and in the future. Within this scope, the research aimed to examine the effect of satisfying the basic psychological needs of secondary school students in physical education on sporting behavior in physical education courses.

\section{Materials and Methods:}

In this section, information about the study group where The Basic Psychological Needs in Physical Education Scale and Physical Education Course Sporting Behavior Scale are applied, the measurement tool and the process related to the analysis of the obtained data are given.

The study group of the research consists of a total of 372

*Corresponding Author:hikmet.turkay@gumushane.edu.tr 
students, 115 of whom are girls and 257 are boys, studying in secondary schools determined by simple random sampling method. The ages of the students vary between the ages of 11-14 and the classes they study in are 5-6-7-8th grades. Students have an average family income level $(85.2 \%)$ and the average education level of their parents (37.9\%) is high school level.

The Basic Psychological Needs in Physical Education Scale (BPN-PE), developed by Vlachopoulos et al., (2011) and adapted to Turkish by Turkay et al. (2019), is a threedimensional (Autonomy, efficacy, and relationship) 7point Likert-type scale consisting of 12 items. In the Turkish adaptation study, it is seen that Cronbach alpha values of the scale vary between 0.67 and 0.75 for secondary school students and arevalid and reliable.

The Physical Education Course Sporting Behavior Scale developed by Koc (2013), is a two-dimensional (displaying sporting behaviors and avoiding unsporting behaviors) 5-point Likert-type scale consisting of 22 items. The scale was applied to 449 secondary school students during the development phase. Cronbach's alpha value (o.85) indicates that the scale is valid and reliable.

In calculating the sample width of this study conducted with the aim of "examining the effect of satisfaction of basic psychological needs on sporting behavior in physical education", the sample width was determined by taking power (test power) at least $80 \%$ and type 1 error $5 \%$ for each variable. Kolmogorov-Smirnov $(\mathrm{n}>50)$ and SkewnessKurtosis tests were used to determine whether the continuous measurements in the study were distributed normally and since they were, Parametric tests were applied. The continuous variables in our study are given as descriptive statistics; mean, standard deviation, minimum, maximum, and categorical variables are given as numbers and percentages. Independent $\mathrm{T}$-test and One-Way Analysis of Variance (ANOVA) were used to compare the scale scores according to categorical demographic variables. Pearson correlation coefficients were calculated to determine the relationships between the scale scores. Chi-squared test was used to determine the relationship between the categorical variables. Statistical significance level (a) was taken as $5 \%$ in the calculations and SPSS (IBM SPSS for Windows, ver.24) statistical package program was used for the calculations.

\section{Resultsand Discussion:}

In this section, statistical analyses of the obtained data are given regarding the relationship between the scales used in the research and the sub-problems of the research.

In the given table, correlation coefficients between scale scores and relationship with age are given. Those whose relationship with each other was found to be statistically significant were shown by asterisk $\left({ }^{*}\right)$. Accordingly, a significant relationship was found between "basic psychological needs" and "sporting behavior". Here, a positive relationship of $17.4 \%$ was observed. A significant relationship was found between "sporting behavior" and "age". Here, a negative relationship of $-11.3 \%$ was observed.

Table 1. Correlation coefficients between the measurements

\begin{tabular}{llll}
\hline & Age & Basic Psychological Needs \\
\hline Psychological Needs & r & .008 & \\
& p. & .876 & $.174^{* *}$ \\
Sporting Behavior & r & $-.113^{*}$ & .001 \\
& p. & .029 & r: Pearson correlation coefficients \\
\hline
\end{tabular}

Table 2. Comparison results of scale scores by gender

\begin{tabular}{|c|c|c|c|c|c|c|}
\hline & $\mathrm{N}$ & Mean & Std. Dev. & Min. & Max. & *p. \\
\hline \multicolumn{7}{|c|}{ Basic Psychological Needs } \\
\hline Girl & 115 & $54 \cdot 72$ & 14.767 & 12 & 84 & \multirow[t]{3}{*}{.131} \\
\hline Boy & 257 & 52.12 & $15 \cdot 583$ & 12 & 87 & \\
\hline Total & 372 & 52.92 & $15 \cdot 363$ & 12 & 87 & \\
\hline \multicolumn{7}{|c|}{ Sporting Behavior } \\
\hline Girl & 115 & 83.54 & 18.466 & 24 & 110 & \multirow[t]{3}{*}{$<.001$} \\
\hline Boy & 257 & $75 \cdot 51$ & 15.619 & 29 & 110 & \\
\hline Total & 372 & $77 \cdot 99$ & 16.939 & 24 & 110 & \\
\hline
\end{tabular}

In the table above, the comparison results of the scale scores by "gender" are given. Basic psychological needs were not affected by "gender". In "sporting behaviour score", however, a statistically significant difference was observed, "by gender". In other words, "sporting behaviour" was affected by "gender". Here, girls scored more than boys.

Table-3: Comparison results of scale scores by extracurricular activities (By Participating in....)

\begin{tabular}{|c|c|c|c|c|c|}
\hline & $\mathrm{N}$ & Mean & SD & Min. & Max. \\
\hline \multicolumn{6}{|c|}{ Basic Psychological Needs $(\mathrm{P}<\mathbf{0 . 0 0 2})$} \\
\hline ....Physical activities & 74 & $59.16^{\mathrm{a}}$ & 13.886 & 31 & 87 \\
\hline ..Social activities & 94 & $52.33^{a b}$ & 17.246 & 12 & 84 \\
\hline ...Cultural activities & 14 & $53.14^{\mathrm{ab}}$ & $15 \cdot 337$ & 26 & 71 \\
\hline ..Artistic activities & 16 & $47 \cdot 56^{\mathrm{b}}$ & 16.162 & 13 & 76 \\
\hline y resting & 174 & $51.06^{\mathrm{ab}}$ & 14.197 & 12 & 84 \\
\hline otal & 372 & 52.92 & $15 \cdot 363$ & 12 & 87 \\
\hline \multicolumn{6}{|c|}{ porting Behavior $(\mathrm{P}<0.912)$} \\
\hline ....Physical activities & 74 & 77.86 & 16.755 & 40 & 110 \\
\hline Social activities & 94 & 78.02 & 14.729 & 50 & 110 \\
\hline ...Cultural activities & 14 & 81.21 & 17.343 & 56 & 102 \\
\hline ....Artistic activities & 16 & 75.06 & 22.170 & 29 & 106 \\
\hline y resting & 174 & 78.04 & $17 \cdot 702$ & 24 & 110 \\
\hline otal & 372 & 77.99 & 16.939 & 24 & 110 \\
\hline
\end{tabular}

In the table above, the comparison results of the scale scores by "extracurricular activities" are given. Accordingly, the "basic psychological needs" were affected by "participation in extracurricular activities". Here, the groups that created the difference are shown with small letters. Accordingly, those who participated in "physical activities" scored higher than those who participated in "artistic activities" and created the difference. On the other hand, "sporting behaviour" was not affected by "participation in extracurricular activities". 
ORIGINAL ARTICLE

Table-4: Comparison results of scale scores by social identification

\begin{tabular}{lccccc}
\hline \multicolumn{7}{c}{$\mathrm{N}$} & Mean & SD & Min. & Max. \\
\hline Basic Psychological Needs & $(\mathbf{P}<\mathbf{0 . 0 0 2})$ & & & \\
Antisocial & 21 & $4^{2.71^{\mathrm{b}}}$ & 17.376 & 12 & 75 \\
Less Social & 65 & $47.46^{\mathrm{b}}$ & 12.678 & $\mathbf{2 2}$ & 71 \\
Social & $\mathbf{2 2 2}$ & $54.42^{\mathrm{a}}$ & 14.925 & 12 & 87 \\
Very Social & 64 & $56.63^{\mathrm{a}}$ & 16.185 & 12 & 84 \\
Total & 372 & 52.92 & 15.363 & 12 & 87 \\
Sporting Behavior $(\mathbf{P}<.439)$ & & & & \\
Antisocial & 21 & 77.05 & 16.821 & 30 & 105 \\
Less Social & 65 & 80.46 & 15.318 & 34 & 110 \\
Social & 222 & 76.95 & 16.687 & 24 & 109 \\
Very Social & 64 & 79.39 & 19.296 & 29 & 110 \\
Total & 372 & 77.99 & 16.939 & 24 & 110 \\
\hline
\end{tabular}

In the table above, the comparison results of the scale scores by "social identification" are given. Accordingly, the "basic psychological needs" have been affected by "social identification". Here, the groups that created the difference are shown with small letters. Accordingly, those who were "very social and social" scored higher than those who were "antisocial and less social" and created the differences. On the other hand, "sporting behaviour" was not affected by "social identification".

Although it is claimed that satisfaction of all three psychological needs (autonomy, efficacy, relationship) is important for personal development, the subject that satisfaction of one of these needs is effective in the development of sportsmanship has been stated in very few studies. Therefore, this research aimed to examine the relationship between satisfying certain psychological needs and the development of sporting behaviours.

When examined by the age variable, it is seen that there is a significant relationship. Smith (1983) stated that the sporting behaviours of hockey players between the ages of 12 and 13 were affected by their coaches and families. According to this result, it can be interpreted that the sporting behaviours of secondary school students within the scope of the research may be affected by their role model teachers and that this behaviour can be learned or enhanced by the attitude of the society regardless of the age of the individual.

In the study, it is seen that the basic psychological needs are not affected by the gender variable. While this finding is not similar to the research findings of Duda (1988), the differences in sporting behaviours between men and women are in line with our research findings. It is seen that women display more sporting behaviour than men. This result is consistent with the literature (Allison, 1982; Silva, 1983; Bredemeier, 1985). In addition, Duda et al. (1991) suggest that girl and boy high school athletes have different understandings of what constitutes fair play or sporting behaviour in sports.

In another variable, basic psychological needs were
Ambient Science, 2020: Vol. 07(Sp1); 176-179 DOI:10.21276/ambi.2020.07.sp1.oa22

affected by participation in extracurricular activities. This finding is consistent with the results of the study conducted by Rolider et al. (1984). The researcher found that extracurricular activities were important in increasing students' positive interactions, satisfying basic psychological needs, and developing sporting behaviours. However, the important point that distinguishes our study from this research is that sporting behaviour was not affected by extracurricular activities in our research. Giebink \& McKenzie (1985) suggest that sportsmanship is an important and integral component of physical education and therefore continuous research should be conducted. They state that these efforts will benefit the analysis of the antecedent and consequential events that control sportsmanship.

The basic psychological needs were affected by students' social identification, but sporting behaviour was not affected by social identification. Ryska (2003) stated in his research that social environments are conceptually compatible with the impact on sportsmanship and the basic principles of self-realization theory. This theory suggests that the personal well-being and social development of individuals are largely due to satisfying innate psychological needs such as autonomy, relationship, and efficacy (Deci \& Ryan, 200o). It can be argued that the level of socialization of an individual positively affects the degree to which they satisfy these basic psychological needs and therefore positively affect their psychological health.

\section{Conclusion:}

This study examines the effect of satisfaction of basic psychological needs on sporting behavior in physical education. The research finds that there is a relationship between satisfying basic psychological needs and the development of sporting behavior and that satisfying basic psychological needs positively affects sporting behavior. Sportsmanship can be learned or enhanced by the structure of sport, the attitude of others, and society. Multiple reasons affect sporting behavior. It is important for parents, teachers, coaches, peers, and the media to model and strengthen sportsmanship. Positive, appropriate, and constructive role models for children are required to teach and enhance sportsmanship and moral reasoning. In addition, it is our primary responsibility to teach sportsmanship to our children, who are our hope for the future.

\section{References:}

Allison, M.T. (1982): Sportsmanship: Variation Based on Sex and Degree of Competitive Experience. In A. O. Dunleavy, A. W. Miracle, \& C. R. Rees (Eds.), Studies in the Sociology of Sport. Pub. by: Fort Worth: Texas Christian University Press.

Bredemeier, B. (1985): Moral reasoning and the perceived legitimacy of intentionally injurious sport acts. I. Sport Psychol.,7:110-124.

Clifford, C. \& Feezell, R.M. (2010): Sport and Character: 
Reclaiming the Principles of Sportsmanship. Pub. by: United States: Human Kinetics.

Deci, E.L. \& Ryan, R.M. (200o): The "what" and "why" of goal pursuits: Human needs and the self-determination of behavior. Psychol. Inq., 11(4):227-268.

Duda, J.L., Olson, L.K. \& Templin, T.J. (1991): The relationship of task and ego orientation to sportsmanship attitudes and the perceived legitimacy of injurious acts. Res. Quart. Exer. Sport, 62(1):79-87.

Duda, J.L. (1988): The relationship between goal perspectives, persistence and behavioral intensity among male and female recreational sport participants. Leisure Sci., 10(2):95-106.

Giebink, M.P. \& McKenzie, T.L. (1985): Teaching sportsmanship in physical education and recreation: An analysis of interventions and generalization effects. J. Teach. Phy. Edu., 4(3):167-177.

Koç, Y. (2013): Beden Egitimi Dersi Sportmenlik Davranisi Ölçegi BEDSDÖ Geçerlik ve Güvenirlik Çalismasi. Erzincan Üniversitesi Egitim Fakültesi Dergisi, 15(1):96-114.

Nucci, C. \& Young-Shim, K. (2005): Improving socialization through sport: An analytic review of literature on aggression and sportsmanship. Phy. Edu., 62(3):123-129.

Reeve, J. \& Jang, H. (2006): What teachers say and do to support students' autonomy during a learning activity. J. Edu. Psychol., 98(1):209.

Ryska, T.A. (2003): Sportsmanship in young athletes: The role of competitiveness, motivational orientation, and perceived purposes of sport.J. Psychol., 137(3):273-293.

Ritchie, L.D., Ivey, S.L., Woodward-Lopez, G. \& Crawford, P.B. (2003): Alarming trends in pediatric overweight in the United States. Sozial-und Präventivmedizin/Social and Preventive Med., 48(3):168-177.
Rolider, A., Cooper, J. \& Van Houten, R. (1984): Effects of Modeling, Instruction, and Grade Incentives on Supportive Verbalizations among Peers in a College Physical Education Class. L. Teach. Phy. Edu., 3(3):44-50.

Smith, M.D. (1983): Violence and Sport. Pub. by: Toronto, Canada: Butterworths. Silva, G. (1983): The perceived legitimacy of rule violating behaviorin sport. J. Sport Psychol., 5:438-338.

Soenens, B., Vansteenkiste, M., Lens, W., Luyckx, K., Goossens, L., Beyers, W. \& Ryan, R.M. (2007): Conceptualizing parental autonomy support: Addescent perceptions of promotion of independence versus promotion of volitional functioning. Develop. Psychol., 43:633-646.

Turkay, H., Mumcu, H.E., Çeviker, A., Güngöz, E. \& Özlü, K. (2019): Beden Egitiminde Temel Psikolojik Ihtiyaçlar Ölçeginin Türkçeye Uyarlanmasi. Gazi Uni. J. Gazi Educational Facul. (GUJGEF), 39(2):1135-1155.

Van den Broeck, A., Vansteenkiste, M., De Witte, H., \& Lens, W. (2008): Explaining the relationships between job characteristics, burnout, and engagement: The role of basic psychological need satisfaction. Work E Stress, 22(3):277294.

Vansteenkiste, M., Matos, L., Lens, W. \& Soenens, B. (2007): Understanding the impact of intrinsic versus extrinsic goal framing on exercise performance: The conflicting role of task and ego involvement. Psychol. Sport Exer., 8(5):771-794.

Vlachopoulos, S.P., Katartzi, E.S. \& Kontou, M.G. (2011): The basic psychological needs in physical education scale. J. Teach. Phy. Edu., 30(3):263-280.

Warburton, D.E., Nicol, C.W. \& Bredin, S.S. (2006): Health benefits of physical activity: the evidence. Cmaj, 174(6):801809 .

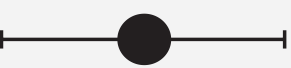

